British \& Irish Botany 2(2): 77-92, 2020

\title{
Changes in the distribution and abundance of Carex ericetorum in Britain since the 1970s
}

\author{
Kevin J. Walker ${ }^{1 *}$; Peter Stroh ${ }^{2}$ \\ ${ }^{1}$ Botanical Society of Britain and Ireland (BSBI), Harrogate, UK; \\ ${ }^{2}$ BSBI, Cambridge, UK.
}

*Corresponding author: Kevin J. Walker: kevin.walker@bsbi.org

This pdf constitutes the Version of Record published on $30^{\text {th }}$ June 2020

\begin{abstract}
British populations of Carex ericetorum Poll. (Rare Spring Sedge) were visited between 2008 and 2015 to assess size, habitats, associated vegetation, management, threats and changes in abundance since the 1970s. C. ericetorum was relocated at 40 of the 64 sites visited, mainly in northwest England (24 sites) and East Anglia (nine sites); most populations that couldn't be relocated were in southern and eastern England. Population sizes were usually small $(<100$ individuals) and had remained relatively stable or had increased in size since the 1970s. In southern and eastern England, C. ericetorum was restricted to speciesrich calcareous grassland overlying chalk or limestone dominated by Festuca ovina and Bromopsis erecta. In northwest England, it was confined to limestone grassland dominated by Sesleria caerulea. Ideal management for $C$. ericetorum comprised autumn and winter grazing to maintain a short sward $(<6 \mathrm{~cm})$, although it had persisted in the absence of grazing where the growth of dominants was restricted by exposure and/or soil infertility. The main threat to its survival is now a lack of grazing leading to increased competition with tall grasses, although agricultural intensification had caused losses in the lowlands. Nitrogen deposition is also likely to have compounded these threats on some sites. Its survival on many sites will require the maintenance or reinstatement of grazing.
\end{abstract}

Keywords: calcareous grassland; management; threats; under-grazing.

\section{Introduction}

Carex ericetorum Poll. (Rare Spring Sedge) is a Boreo-temperate sedge that occurs throughout northern and central Europe from Scandinavia and northern Russia (to $68^{\circ} \mathrm{N}$ ), as far south as northern Spain, central France, northern Italy, the Balkans, Bulgaria and the Caucasus. Its range extends as far east as the Siberian Urals and reaches its western limit in England (David, 1981). As the common name implies, it is a rare species in Britain, confined to East Anglia, the Midlands and northern England where it reaches its altitudinal limit at $545 \mathrm{~m}$ OD 
on Cronkley Fell, Upper Teesdale. Due to its restricted range and recent declines it has been assessed as 'Vulnerable' in Great Britain and England (Cheffings \& Farrell, 2005; Stroh et al., 2014). It has also declined in Continental Europe and is assessed as 'Critically Endangered' in Belgium and the French regions of Burgundy, Centre-Val de Loire and Champagne-Ardenne. It is categorised as 'Endangered' in the Czech Republic, Germany and the Parisian region of Île de France, and, as in England, it is 'Vulnerable' in Hungary and the regions of Auvergne in Central France and Picardy in northern France (Stroh et al., 2014).

In the 1970s David (1981) surveyed British populations of C. ericetorum in order to update the distribution map included in a revised monograph of British sedges (Jermy et al., 1982). His paper included information on historic and extant sites, based on a review of historical records, herbarium specimens, and field surveys. The presence of $C$. ericetorum was confirmed at 35 of 48 historical sites, with losses attributed to agricultural improvement, quarrying and trampling by visitors. Between 2008 and 2013 Botanical Society of Britain and Ireland (BSBI) recorders re-visited a sample of these sites as part of the BSBI's Threatened Plants Project (TPP), in order to assess the species' status and inform its future conservation; during these visits volunteers collected information on population size and extent, regeneration, associated species, habitats, management and threats (Walker et al., 2017). Given the good coverage achieved by TPP recorders, the authors extended this survey to include all currently known sites, with a few notable exceptions (see text below).

In this paper we present the results of this survey; specifically, we summarise (1) the past and present distribution of $C$. ericetorum in Britain including changes in the number and size of populations since the 1970s, (2) its habitats and management, and (3) the threats to its survival or reasons for its loss on sites where it is no longer present. Nomenclature follows Stace (2019) for vascular plants and Rodwell (1991-2008) for National Vegetation Classification (NVC) communities.

\section{Methods}

Between 2008 and 2013 BSBI recorders visited 23 historic sites, selected at random from those held in the BSBI's distribution database as part of the TPP survey (Walker et al., 2017). An additional 41 sites not included in this sample were identified from David (1981), BSBI records, unpublished reports (e.g. Blakemore, undated) and through correspondence with botanists familiar with the species. All these sites were visited by the authors or TTP recorders, except 11 sites where $C$. ericetorum was known to be extinct and four East Anglian sites with restricted access due to military activities (Bodney Warren) or breeding Stone Curlews (Burhinus oedicnemus) (Lakenheath Warren, Foxhole Heath, Deadman's Grave). However, the presence of $C$. ericetorum was confirmed at three of these sites during brief surveys in 2008 (Nick Gibbons, pers. comm.). Details of all the sites included in this survey are given in the Appendix. 
Field surveys were carried out between April and July when C. ericetorum was in flower or fruit. On sites where $C$. ericetorum was refound its distribution was mapped to $10 \times 10 \mathrm{~m}$ resolution using a handheld GPS, the size and the extent of the population estimated and notes taken on topography (slope and aspect), habitats, management and threats that were obvious at the time of the survey. The abundance of associated vascular plants was also recorded using the DAFOR scale in at least one $2 \mathrm{~m}$ diameter circular quadrat located in an area of representative vegetation containing $C$. ericetorum. The probable reasons for loss were also recorded on sites where $C$. ericetorum could not be refound.

Quadrat data, including additional samples taken from Fearn (1971), were assigned to NVC communities using Tablefit (Hill, 2015) and differences in community composition were explored using Detrended Correspondence Analysis carried out in Vegan for R (Version 2.5-6; Oksaninen et al., 2019), with rare species downweighted.

\section{Results}

Discovery

The early history of $C$. ericetorum in Britain is rather confused. A specimen collected in 1833 (not 1838 as originally described) from the Gog Magog Hills near to Cambridge was not correctly identified as C. ericetorum until 1861, when its discoverer, Charles Babington, determined specimens collected by him and John Ball from the same site as C. ericetorum (Babington, 1861; Bennett, 1910). Subsequently a specimen collected from Mildenhall Heath, West Suffolk, in 1829, and originally identified by Sir W. C. Trevelyan as C. pilulifera, was also found to be $C$. ericetorum (David, 1981). A possibly earlier record, however, is Sir John Cullum's record of C. montana from Newmarket Heath in 1775-76. The two species are very similar but $C$. montana, as currently understood, is confined to south-west England and Wales, and $C$. ericetorum is known to have occurred at the site till 1954 (Leslie, 2019). C. ericetorum is, therefore, the more likely species connected with the Cullum record (Bennett, 1910), although unfortunately no specimen has been traced. All other discoveries in the late nineteenth and early twentieth century were from East Anglia, with a first record for East Norfolk in 1880 and additional sites for West Suffolk and Cambridgeshire (Table 1).

C. ericetorum was discovered in northern England in 1943 when Ted (E.C.) Wallace found a small colony in limestone grassland near to Burton Leonard, Mid-west Yorkshire (Wallace, 1943). In the following decade it was found at a range of sites on limestone elsewhere in northern England, as predicted by Wallace (1943), including Scout Scar, Westmorland in 1944, Markland Grips, Derbyshire in 1945, Lindrick Common, South-west Yorkshire in 1945 (Brown, 1945) and, most notably, Widdybank Fell in Upper Teesdale, where T.G. Tutin discovered it growing with Viola rupestris on sugar limestone outcrops in 1949 (Wallace, 1951). 
Table 1. The number and current status of populations of Carex ericetorum ( $n$ $=64$ ) recorded in British vice-counties listed in order of the year of discovery.

\begin{tabular}{lccccc}
\hline Vice-county (v.c.) & First record & Extant & Extinct & Total & \% lost \\
\hline Cambridgeshire (29)* & 1775 & 1 & 4 & 5 & 80 \\
West Suffolk (26) & 1829 & 5 & 2 & 7 & 29 \\
East Norfolk (28) & 1880 & 4 & 6 & 10 & 60 \\
Mid-west Yorkshire (64) & 1943 & 2 & 3 & 5 & 60 \\
Westmorland (69) & 1944 & 14 & 1 & 15 & 7 \\
Derbyshire (57) & 1945 & 1 & 0 & 1 & 0 \\
South-west Yorkshire (63) & 1945 & 2 & 1 & 3 & 33 \\
Durham (66) & 1949 & 1 & 1 & 2 & 50 \\
South Lincolnshire (53) & 1950 & 0 & 1 & 1 & 100 \\
North-west Yorkshire (65) & 1950 & 5 & 0 & 5 & 0 \\
North Lincolnshire (54) & 1951 & 0 & 1 & 1 & 100 \\
North Lancashire (60) & 1951 & 4 & 4 & 8 & 50 \\
Northamptonshire (32) & 1978 & 1 & 0 & 1 & 0 \\
Total & & 40 & 24 & 64 & 38 \\
\hline
\end{tabular}

* 'Newmarket Heath' straddles the boundary of Cambridgeshire and West Suffolk but the area most likely to have supported C. ericetorum is in v.c.29.

Between 1950 and 1980, 30 new populations were discovered, 23 of which were in the Midlands or northern England, including first records for South and North Lincolnshire (Ancaster, 1950; Broughton, 1951), North Lancashire (Hawes Water, 1951), North-west Yorkshire (Cronkley Fell, 1950) and Northamptonshire (Barnack Hills and Holes, 1978) (Fig. 1). Further populations have been found since 1980, mainly on the limestones near to Morecambe Bay (North Lancashire, Westmorland) and above Orton in Cumberland. Three new populations were discovered during the current survey (Ledsham, Mid-west Yorkshire; Heathwaite, Westmorland; Pott Rigg, Cumberland).

\section{Number of populations}

Since its discovery in 1775, Carex ericetorum has been found in 64 sites in 13 vice-counties in England, with unconfirmed records from a further six sites (Table 1 ; Appendix). These sites are located within 32 hectads $(10 \times 10 \mathrm{~km}$ grid squares), 19 of which contain extant populations (Fig. 2). The number of populations has increased dramatically since its discovery in northern England in 1943, with 53 populations discovered since then (Fig. 1). The main strongholds for the species are the limestones around Morecambe Bay, above Orton in Westmorland, Upper Teesdale, and the chalk-heaths of the Breckland region of East Norfolk and West Suffolk (Table 1). In comparison, only single populations survive in Cambridgeshire (Devil's Ditch), Northamptonshire (Barnack Hills and Holes), Derbyshire (Markland Grips) and Durham (Widdybank Fell), and the 
species has not been recorded in North or South Lincolnshire since 1993 and 1996 respectively.

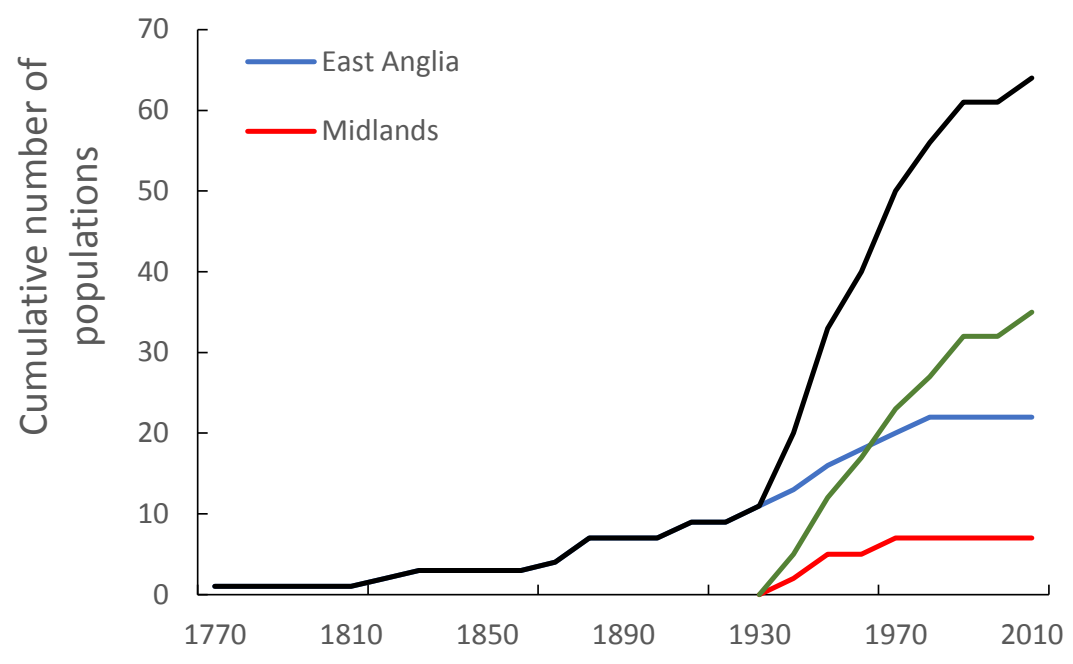

Figure 1. Cumulative number of Carex ericetorum populations discovered in England shown by region.
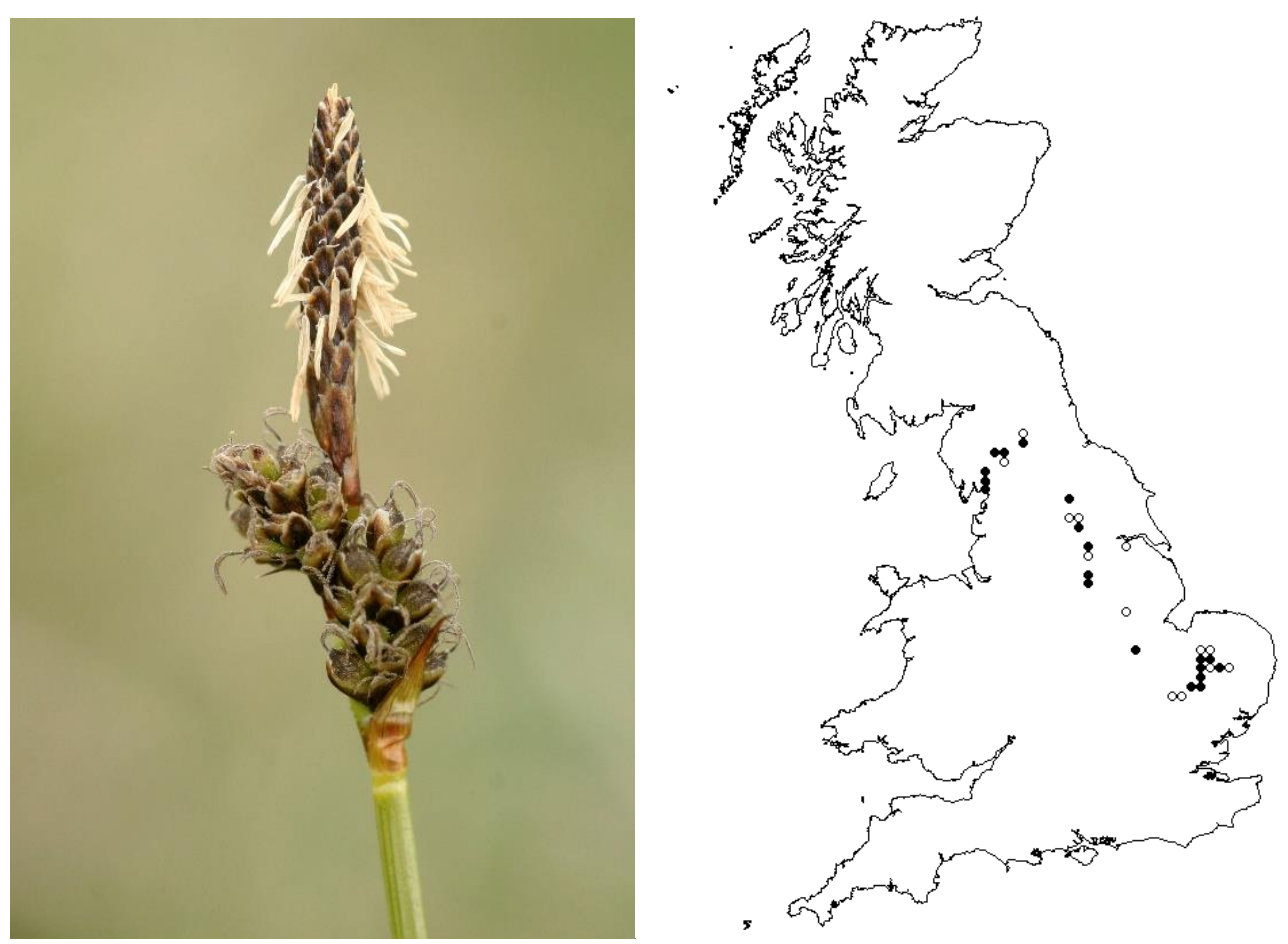

Figure 2. Carex ericetorum. Inflorescence (left) and hectad distribution in Great Britain (right). Solid black dots are $10 \times 10 \mathrm{~km}$ grid squares (hectads) in which C. ericetorum has been recorded since 2000; open circles indicate hectads with records before 2000 but not since. 


\section{Losses}

Carex ericetorum has been lost from 24 sites (38\%) (Table 1), mainly in the lowlands of southern and eastern England. Populations in Cambridgeshire have been worst affected by changes in land-use (see below), with post-2000 records from only one site on the Devil's Ditch, although it has not been seen here since 2010 despite careful searching each year, and it seems likely that it is now extinct in the vice-county (Leslie, 2019). It is extinct in both North and South Lincolnshire, has been lost from six of 10 sites in East Norfolk (Cockley Cley, Cranwich, East Harling, Garboldisham, Gooderstone Common, Jubilee Wood), and three of five sites in Mid-west Yorkshire (Hetchell Crags, Jackdaw Crag Quarry, Linton Common). The majority of these localised extinctions have occurred since the 1940s, and losses continued into the current century.

Most of these losses occurred on lowland chalk grasslands and chalk grassheaths due to ploughing, agricultural intensification or land abandonment following the cessation of grazing (Table 2). Populations in lowland limestone grasslands also suffered relatively high losses, for the same reasons as well as the quarrying of limestone for roadbuilding and construction. In comparison, most upland populations have survived (Table 2), presumably because their remoteness and topography have made them more difficult to intensify for agricultural purposes. Furthermore, nearly most upland sites have been designated as SSSIs and are now managed for conservation objectives, although changes in grazing regimes in recent years have led to local declines (see below).

Table 2. Populations of Carex ericetorum in relation to habitat.

\begin{tabular}{lcccc}
\hline Habitat & Extant & Extinct & Total & $\%$ lost \\
\hline Chalk grassland & 2 & 5 & 7 & 71 \\
Chalk grass-heath & 8 & 7 & 15 & 47 \\
Limestone grassland - lowland & 16 & 10 & 26 & 38 \\
Limestone grassland - upland & 14 & 2 & 16 & 13 \\
Total & 40 & 24 & 64 & 38 \\
\hline
\end{tabular}

Size of populations

Population size was estimated by David (1981) and during this survey using broad abundance categories (Table 3). By the 1970s a quarter of populations had been lost whereas two-thirds supported fewer than 100 plants $(n=27)$ and only three had more than 1000 individuals. During the current survey the number of losses had almost doubled to $40 \%$, due to the loss of many of the populations that were identified as being critically small by David (1981) (e.g. Ancaster, Brodsworth, Broughton, West Wratting). In comparison, proportion of larger populations increased from $11-17 \%$ due to the discovery of some very extensive populations in upland areas of northern England (e.g. Long Scar Pike, 
Scout Scar, Ravensworth Fell) whereas the proportion of the largest populations (>1000 individuals) stayed the same at $7 \%$.

Table 3. Number and percentage (in parentheses) of British Carex ericetorum populations according to population size class in 1970s $(n=46)$ and during current survey $(\mathbf{n}=\mathbf{5 8})$.

\begin{tabular}{|c|c|c|}
\hline Population size & 1970s & $2008-2015$ \\
\hline Extinct & $11 \quad(24)$ & $23 \quad(40)$ \\
\hline $1-20$ individuals & 11 (24) & (9) \\
\hline 21-100 individuals & $16(35)$ & $16(28)$ \\
\hline $101-1000$ individuals & $5(11)$ & (17) \\
\hline$>1000$ individuals & $3(7)$ & (7) \\
\hline
\end{tabular}

*Population sizes were not estimated on six sites during the current survey (Bodney Warren, Crosby Gill, Deadman's Grave, Lakenheath Warren, Foxhole Heath, Gooderstone Common).

The numbers of individuals appear to have increased at nine sites since the 1970s, mainly in northern England, whereas five have remained the same (Table 4). Two populations in East Anglia have declined but are still extant (Grime's Graves, Knettishall Heath) and five have declined to extinction, including three in the Midlands (Ancaster, Brodsworth, Broughton). Eleven populations thought to be extinct in the 1970s were revisited during the current survey, mainly in East Anglia, and no plants were relocated confirming the local extirpation of $C$. ericetorum at these sites (Table 4).

Table 4. Number of populations of British Carex ericetorum according to region and trend in population size. Final column is total numbers and the percentage of British populations according to trend in population size.

\begin{tabular}{lccccc}
\hline Trend & East Anglia & Midlands & North & Total & $\%$ \\
\hline Increase & 2 & 3 & 4 & 9 & 28 \\
Stable & 2 & 0 & 3 & 5 & 16 \\
Decline - still extant & 2 & 0 & 0 & 2 & 6 \\
Decline - extinct & 1 & 3 & 1 & 5 & 16 \\
Extinct - pre-1970 & 8 & 0 & 3 & 11 & 34 \\
Total & 15 & 6 & 11 & 32 & 100 \\
\hline
\end{tabular}

Vegetation communities

Carex ericetorum was recorded in all but one of the lowland calcareous grassland types recognized by the National Vegetation Classification (NVC), as well as a single lowland acid grassland type (Fig. 3). In East Anglia C. ericetorum is a characteristic member of the Breck grass-heath community first described by Watt $(1940,1957)$ that occurs on sandy soils overlying chalk where soil reaction either exceeds pH 6 (Watt's so-called 'Grassland B'), now referable to Festuca 
ovina-Hieracium pilosella-Thymus praecox/pulegioides chalk grassland (NVC CG7), or where soil pH is lower (Watt's 'Grassland C'), Festuca ovina-Agrostis capillaris-Rumex acetosella acid grassland (NVC U1) (Pakeman \& Marshall, 1997). These dry grasslands are often associated with periglacial 'patterned ground' that formed at the end of the last glaciation (Watt et al., 1966) and now support alternating 'stripes' of calcicole and calcifuge vegetation (David, 1994). A good example of this habitat type survives at Grime's Graves where $C$. ericetorum occurs locally on the edge a small chalk pit and along ridges of calcareous grassland running away from it into the adjacent heathland (see Fig. 4 , top left). This vegetation type forms a distinct cluster on the second axis of the DCA diagram below with a single sample assigned to $U 1$ grassland recorded on Lakenheath Warren (Fig. 3). Elsewhere on the East Anglian chalk $C$. ericetorum occurs in species-rich calcareous grasslands dominated by Festuca ovina and Bromopsis erecta (NVC CG1/2/3); these communities also occur sporadically on carboniferous and magnesian limestones throughout the lowland range of the species including Jack Scout in North Lancashire, Markland Grips in Derbyshire and Burton Leonard in Mid-west Yorkshire.

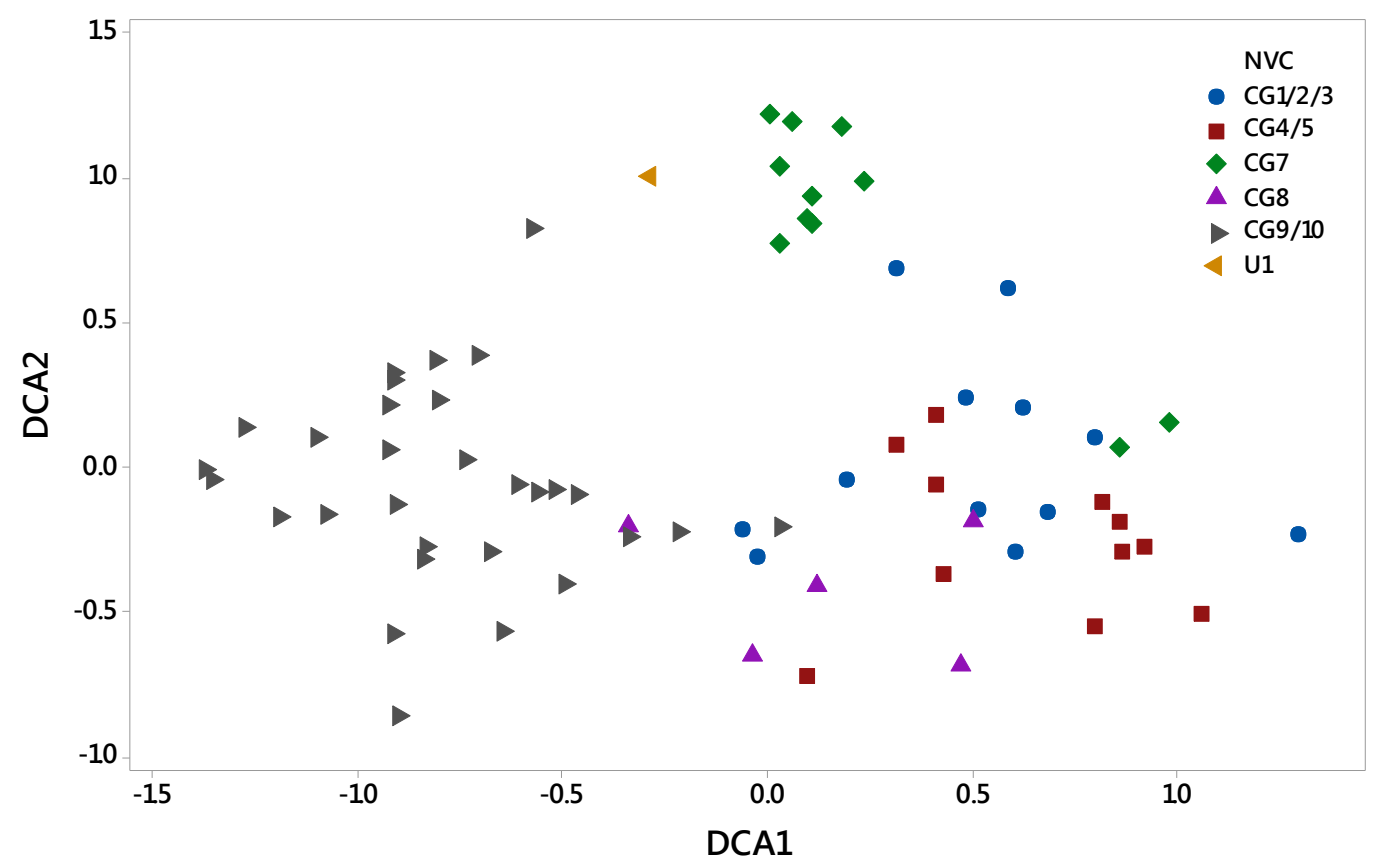

Figure 3. Ordination diagram of species abundance in $1 \times 1 \mathrm{~m}$ vegetation quadrats containing Carex ericetorum. Sample scores were calculated using Detrended Correspondence Analysis (DCA) with rare species downweighted. Eigenvalues for axes: $D C A 1=0.32$; $D C A 2=0.19$. Axis lengths: $D C A 1=2.68$; DCA2 $=2.08$. NVC types are superimposed on sample scores.

In eastern England $C$. ericetorum occurs on limestone in grasslands dominated by Bromopsis erecta and/or Brachypodium pinnatum (NVC CG4/5) that are similar in composition to NVC CG1/2/3 and therefore show a high 
degree of overlap on the first and second axes of the DCA (Fig. 3). These include the isolated populations in ancient quarry workings at Barnack Hills and Holes in Northamptonshire and Lindrick Common near to Worksop and Ledsham and Madbanks SSSI in Yorkshire where $C$. ericetorum was discovered during this survey in 2013.

On carboniferous limestones in northwest England $C$. ericetorum occurs exclusively in Sesleria albicans-Galium sterneri grassland (NVC CG9), usually on shallow soils around limestone outcrops and more locally on the sunnier aspects of ant-hills (Walker \& Jefferson, 2019). In Upper Teesdale it is also a characteristic member of the 'Teesdale assemblage' growing in CG9 grassland on the eroded edges of sugar limestone outcrops on both Widdybank and Cronkley Fells (Bradshaw, 1985). Nearer to sea-level around Morecambe Bay it also occurs very locally within Sesleria albicans-Scabiosa columbaria grassland (NVC CG8) and at Burnbarrow Scar near to Kendal it occurs within Festuca ovina-Agrostis capillaris-Thymus praecox grassland (NVC 10).

\section{Management}

Like many threatened plants of unimproved grasslands, Carex ericetorum is reliant on grazing to reduce the dominance of more competitive species (Walker \& Jefferson, 2019). This is usually achieved by grazing with hardy breeds of sheep or cattle, in combination with low soil fertility and/or exposure on sites at higher altitudes. Ideally grazing should occur during the late summer, autumn and winter months allowing $C$. ericetorum time to flower and set seed. However, it survives in taller swards through the production of elongated leaves (Watt, 1974), and in the absence of grazing where the soils are very shallow and infertile (Watt, 1957). For example, it has persisted for decades in grazing exclosures in Breckland (Watt, 1981) and on Cronkley Fell in Teesdale (Elkington, 1981).

On lowland sites where grazing has been lost cutting in the late summer has also being used to maintain short swards (e.g. Burton Loenard Lime Quarries in Yorkshire). At other sites periodic removal of scrub or trees has been carried out where these have threatened populations (e.g. Barnack Hills and Holes NNR, Northamptonshire). On a few lowland sites, however, scrub encroachment has been so severe that populations have been completely lost (e.g. Broughton, Fleam Dyke, Ancaster Valley).

\section{Threats}

In recent decades the main threat to Carex ericetorum has been reductions in grazing leading to the replacement of short turf by taller more competitive swards and scrub (Table 5). This has been particularly prevalent on limestone grasslands, especially in the lowlands, where surviving fragments of species-rich grassland are no longer grazed as frequently as they once were due to the difficulties of sustaining livestock on small, isolated sites often 'managed' as nature reserves. Lack of grazing is also the sole reported threat to populations in 
the uplands due to a general decline in numbers of sheep (following Foot-andMouth disease) and in some areas a shift to more extensive cattle grazing. On some sites (e.g. Orton Scar, Widdybank Fell) this has led to the development of much taller swards dominated by Ses/eria caerulea amongst which it is becoming increasingly difficult to find $C$. ericetorum.

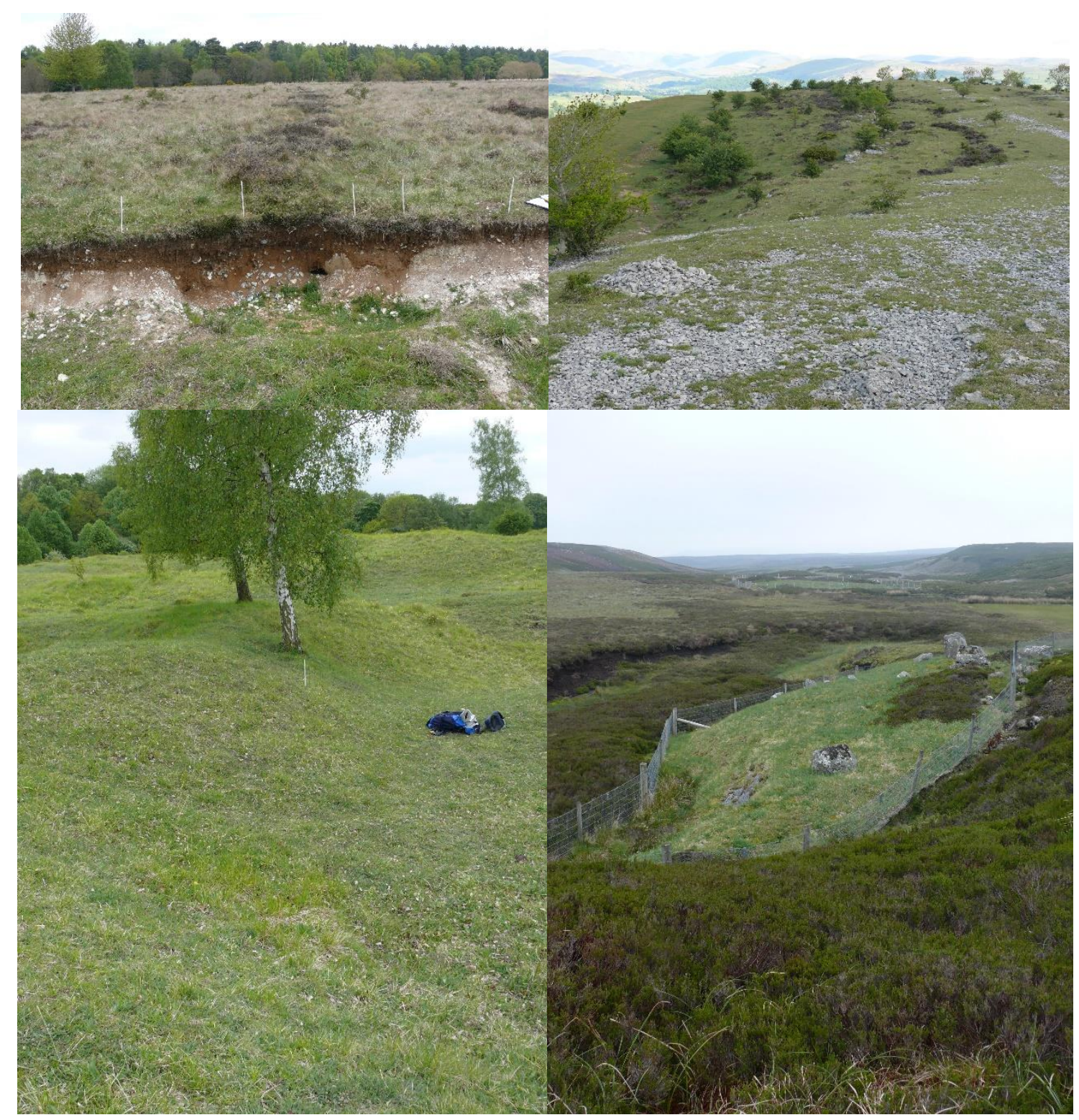

Figure 4. Some habitats of Carex ericetorum in the British Isles (white markers indicate where the plant occurs): top left, grass-heath at Grime's Graves, Breckland; top right, limestone grassland dominated by Ses/eria ablicans on Cunswick Scar, Westmorland; bottom left, Bromopsis erecta grassland in medieval limestone quarries at Barnack Hills and Holes NNR, Northamptonshire; bottom right, sugar limestone outcrop on Cronkley Fell, Upper Teesdale. 
As in the 1970s (David, 1981) agricultural intensification (e.g. fertilisation, re-seeding, over-stocking) remains a threat to some populations in the lowlands as are afforestation and competition with invasive species although the latter may be a symptom of a lack of management mentioned above on some sites. All others threats were very local and included the loss of grassland to housing developments, quarrying and, perhaps most famously, the construction of Cow Green Reservoir in Upper Teesdale, which led to the loss of $c .40 \%$ of the Widdybank Fell population (including an outlying population at Slapestone Syke) during its construction (Bradshaw, 1985).

Although not explicitly mentioned by surveyors, it seems likely that eutrophication may be contributing to these declines in areas where deposition of atmospheric pollutants from human sources is high. Evidence for this has been shown experimentally in Upper Teesdale where $C$. ericetorum, along with other rare species, were almost entirely eliminated through competition with tall grasses on plots treated with phosphorous and nitrogen (Jeffrey \& Pigott, 1973). More generally long-term monitoring of plots within calcareous grasslands in Britain, including some supporting populations of $C$. ericetorum (e.g. Cronkley Fell), has shown a general decline in plant diversity including the loss or rare and scarce species in response to increases in $\mathrm{N}$ deposition over recent decades (Van Den Berg et al., 2010).

Table 5. Threats to populations of Carex ericetorum assessed during field visits 2008-2015.

\begin{tabular}{lccccc}
\hline \multirow{2}{*}{ Threat } & \multicolumn{2}{c}{ Chalk } & \multicolumn{2}{c}{ Limestone } & Total \\
\cline { 2 - 5 } & grass-heath & grassland & lowland & upland & \\
\hline Lack of grazing & 3 & 4 & 14 & 8 & 29 \\
Agricultural intensification & 3 & 2 & 3 & 0 & 8 \\
Afforestation & 1 & 0 & 4 & 0 & 5 \\
Invasive species & 0 & 1 & 3 & 0 & 4 \\
Recreation & 1 & 0 & 1 & 0 & 2 \\
Burning & 0 & 0 & 1 & 0 & 1 \\
Development & 0 & 0 & 1 & 0 & 1 \\
Quarrying & 0 & 0 & 1 & 0 & 1 \\
Reservoir & 0 & 0 & 0 & 1 & 1 \\
Disturbance & 1 & 0 & 0 & 0 & 1 \\
\hline
\end{tabular}

\section{Conclusions}

Carex ericetorum remains one of Britain's rarest sedges and the decline first quantified by David (1981) has continued albeit modestly till the present day. Whereas in the past most of these losses were due to the ploughing-up of grassland for cultivation or the intensification of grassland management for 
livestock production, more recently lack of management has become the main threat. This is because many of its sites are managed as nature reserves by organisations that often lack the resources and livestock to maintain grazing regimes. These effects are likely to have been compounded by increased eutrophication from human and agricultural sources (e.g. atmospheric pollution, fertilizer drift, etc.). Having said that, these losses in the lowlands have been mitigated to some extent by the discovery of large populations in the uplands, some extending over very large areas (e.g. Scout \& Cunswick Scar, Crosby Ravensworth Fell, Widdybank and Cronkley Fells). Large populations also persist in Breckland although its status there seems more precarious due to greater pressures from human and agricultural activities. Away from these strongholds $C$. ericetorum remains critically endangered with tiny populations isolated on one or two sites in six vice-counties, including Cambridgeshire where it may already be extinct (Leslie, 2019). The fact that all surviving populations occur on SSSIs means that hopefully funding will be made available to maintain or restore grazing to the levels needed to ensure its long-term survival.

\section{Acknowledgements}

We'd like to thank Nick Gibbons for providing information on sites in East Anglia, Mike Porter, Jeremy Roberts, Linda Robinson and Peter Bullard for their assistance with surveys in northern England and James Symonds for providing us with access to Weeting Heath. We would also like to thank the BSBI recorders who carried out surveys of $C$. ericetorum for the Threatened Plants Project (https://bsbi.org/threatened-plants-project) namely H.E. Aldridge, D. Barden, Neil Crossman, M. Edmunds, Bob Ellis, Monica Frisch, M.P. Ghullam, T. Graham, Eric Greenwood, S. Hartley, A. Jepson, Paul Kirby, J. Lamb, Peter Lambley, Alan Leslie, J.M. Newton, C.L. Roberts, Jonathon Shanklin, Simon Smart, and Alan Wilmott. Finally, we would like to thank David Pearman and John Hunnex for help with historical records.

\section{References}

Bennett, A. 1910. Medicago sylvestris, M. falcata, Carex ericetorum and Psamma baltica in England with a note on Scleranthus perennis. Transactions of Norfolk and Norwich Naturalists Society 9: 16-25.

Blakemore, J. undated. North-east Yorkshire Rare Plant Survey. Durham: Volume 2. Peterborough: English Nature.

Babington, C.C. 1861. On the discovery of Carex ericetorum, Poll., as a native of Britain. Journal of the Proceedings of the Linnaean Society of London Botany 6: 30-31.

Bradshaw, M.E. 1985. Studies on the flora of Teesdale. The Naturalist 110: 3-21. Bradshaw, M.E. \& Doody, J.P. 1978. Plant population studies and their relevance to nature conservation. Biological Conservation 14: 223-242.

Brown, J. 1945. Carex ericetorum Poll. in South-west Yorkshire and Derbyshire. The Naturalist 812: 111. 
Cheffings, C. \& Farrell, L. 2005. The Vascular Plant Red Data List for Great

Britain. Species Status 7: 1-116. Peterborough: Joint Nature Conservation

Committee.

Crompton, G. 2019. Cambridgeshire Flora Records since 1538. Online catalogue: http://www.mnlg.com/gc/index2.html [accessed April 2019].

David, R.W. 1981. The distribution of Carex ericetorum Poll. in Britain. Watsonia, 13: 225-226. http://archive.bsbi.org.uk/Wats13p225.pdf

David, R.W. 1994. Carex ericetorum, in A. Stewart, D.A Pearman \& C.D. Preston (eds) Scarce Plants in Britain. Peterborough: Joint Nature Conservation Committee, pp.84-85.

Elkington, T.T. 1981. Effects of excluding grazing animals from grassland on sugar limestone in Teesdale, England. Biological Conservation 20: 25-35.

Jeffrey, D.W. \& Pigott, C.D. 1973. The response of grasslands on sugarlimestone in Teesdale to applications of phosphorous and nitrogen. Journal of Ecology 61: 85-92.

Fearn, G.M. 1971. Biosystematic studies of selected species in the Teesdale flora. $\mathrm{PhD}$ thesis, University of Sheffield.

Hill, M.O. 2015. TABLEFIT version 2.0 for the identification of vegetation types. Wallingford: Centre for Ecology \& Hydrology.

Jermy, A.C., Chater, A.O. \& David, R.W. 1982. Sedges of the British Isles. $2^{\text {nd }}$. ed. London: Botanical Society of the British Isles.

Leslie, A.C. 2019. Flora of Cambridgeshire. Peterborough: Royal Horticultural Society.

Oksaninen, J., Blanchet, F.G., Friendly, M., Kindt, R., Legendre, P., McGlinn, D., Minchin, P.R., O'Hara, R.B., Simpson, G.L., Solymos, P., Stevens, M.H.H., Szoecs, E. \& Wagner, H. 2019. Package 'Vegan'. Version 2.5-6. https://cran.r-project.org/web/packages/vegan/vegan.pdf

Pakeman, R. \& Marshall, A.G. 1997. The seedbanks of the Breckland heaths and heath grasslands, eastern England, and their relationships to the vegetation and the effects of management. Journal of Biogeography 24: 375-390.

Rodwell, J.S. 1991-2008. British Plant Communities. Volumes 1-5. Cambridge: Cambridge University Press.

Stace, C.A. 2019. New Flora of the British Isles, $4^{\text {th }}$ ed. Middlewood Green, Suffolk: C. \& M. Floristics.

Stroh, P.A., Leach, S.J., August, T.A., Walker, K.J., Pearman, D.A., Rumsey, F.J., Harrower, C.A., Fay, M.F., Martin, J.P., Pankhurst, T., Preston C.D. \& Taylor, I. 2014. A Vascular Plant Red List for England. Bristol: Botanical Society of Britain and Ireland.

Van Den Berg, L.J.L., Vergeer, P., Rich, T.C., Smart, S.M., Guest, D. \& Ashmore, M. 2010. Direct and indirect effects of nitrogen deposition on species composition change in calcareous grasslands. Global Change Biology 117: 1871-183.

Wallace, E.C. 1943. Carex ericetorum Poll. in Yorkshire. The Naturalist 814: 97. Wallace, E.C. 1951. Plant records. Watsonia 2: 36-62. 
Walker, K.J., Stroh, P.A. \& Ellis, R.W. 2017. Threatened Plants in Britain and Ireland. Bristol: Botanical Society of Britain and Ireland.

Walker, K.J. \& Jefferson, R.G. 2019. Carex ericetorum Rare Spring-sedge, in P.A. Stroh, K.J. Walker, S. Smith, R. Jefferson, C. Pinches \& T. Blackstock (eds.) Grassland Plants of the British and Irish Lowlands. Durham: Botanical Society of Britain and Ireland, pp. 69-71.

Watt, A.S. 1940. Studies in the ecology of Breckland. IV. The grass-heath. Journal of Ecology, 28: 42-70.

Watt, A.S. 1957. The effect of excluding rabbits from Grassland B (Mesobrometum) in Breckland. Journal of Ecology 45: 861-878.

Watt, A.S. 1974. Senescence and rejuvenation in ungrazed chalk grassland (Grassland B) in Breckland: the significance of litter and of moles. Journal of Ecology 11: 1157-1171.

Watt, A.S. 1981. A comparison of grazed versus ungrazed Grassland A in East Anglian Breckland. Journal of Ecology 69: 499-508.

Watt, A.S., Perrin, R.M.S. \& West, R.G. 1966. Patterned ground in Breckland: structure and composition. Journal of Ecology 54: 239-258.

Copyright retained by author(s). Published by BSBI under the terms of the Creative Commons Attribution 4.0 International Public License.

ISSN: $2632-4970$

https://doi.org/10.33928/bib.2020.02.077 
Appendix. Details of the 64 British populations of Carex ericetorum included in this study. Populations sizes for the 1970s were taken from David (1981). See notes below this table for an explanation of the codes used for populations sizes, habitat and National Vegetation Classification communities (NVC).

\begin{tabular}{|c|c|c|c|c|c|c|c|}
\hline \multirow{2}{*}{ Locality } & \multirow{2}{*}{ VC } & \multirow{2}{*}{ First } & \multirow{2}{*}{ Last } & \multirow{2}{*}{ Habitat } & \multirow{2}{*}{ NVC } & \multicolumn{2}{|c|}{ Population size } \\
\hline & & & & & & $1970 \mathrm{~s}$ & $2008-15$ \\
\hline Deadman's Grave & 26 & 1877 & - & $\mathrm{CGH}$ & CG7 & B & $P$ \\
\hline Foxhole Heath & 26 & 1829 & - & $\mathrm{CGH}$ & CG7 & B & $P$ \\
\hline Knettishall Heath & 26 & 1977 & - & $\mathrm{CGH}$ & CG3 & B & $A$ \\
\hline Lakenheath Warren & 26 & $1930 s$ & - & $\mathrm{CGH}$ & U1 & $\mathrm{D}$ & $P$ \\
\hline Risby Black Ditches & 26 & 1888 & - & CGE & CG7 & B & $\mathrm{C}$ \\
\hline Weather Heath & 26 & 1884 & 1983 & $\mathrm{CGH}$ & - & $x$ & $X$ \\
\hline Worlington & 26 & 1983 & 1983 & $\mathrm{CGH}$ & - & NV & $X$ \\
\hline Bodney Warren & 28 & 1980 & - & $\mathrm{CGH}$ & $?$ & $B$ & $\mathrm{P}$ \\
\hline Cockley Cley & 28 & 1916 & $<1968$ & $\mathrm{CGH}$ & - & $X$ & $X$ \\
\hline Cranwich & 28 & $<1968$ & 1968 & $\mathrm{CGH}$ & - & $X$ & $X$ \\
\hline East Harling & 28 & 1949 & $<1970$ & $\mathrm{CGH}$ & - & $x$ & $X$ \\
\hline Foulden Common & 28 & 1946 & - & $\mathrm{CGH}$ & CG2 & B & $\mathrm{C}$ \\
\hline Garboldisham & 28 & 1957 & 1975 & CGE & - & $X$ & $X$ \\
\hline Gooderstone Common & 28 & 1977 & $?$ & $\mathrm{CGH}$ & $?$ & B & $?$ \\
\hline Grime's Graves & 28 & 1951 & - & $\mathrm{CGH}$ & CG7 & $\mathrm{C}$ & B \\
\hline Jubilee Wood & 28 & 1880 & 1968 & $\mathrm{CGH}$ & - & $X$ & $X$ \\
\hline Weeting Heath & 28 & 1956 & - & $\mathrm{CGH}$ & CG7 & $\mathrm{D}$ & $\mathrm{D}$ \\
\hline Devil's Ditch & 29 & 1911 & - & EWC & CG3 & $A$ & $A$ \\
\hline Fleam Dyke & 29 & 1965 & 1972 & CG & - & $X$ & $X$ \\
\hline Gogmagog Hills & 29 & 1833 & 1896 & CG & - & $X$ & $X$ \\
\hline Newmarket Heath & 29 & 1775 & 1954 & CG & - & NV & $X$ \\
\hline West Wratting & 29 & 1936 & 1974 & CG & - & $A$ & $X$ \\
\hline Barnack Hills \& Holes & 32 & 1978 & - & LGQ & CG5 & NV & $B$ \\
\hline Ancaster Valley & 53 & 1950 & 1996 & LG & - & $A$ & $x$ \\
\hline Broughton & 54 & 1951 & 1993 & LG & - & $A$ & $X$ \\
\hline Markland Grips & 57 & 1945 & - & LG & CG3/5 & $A$ & B \\
\hline Silverdale Golf Course & 60 & 1974 & - & LG & $\mathrm{CG} 3 / 8$ & - & $B$ \\
\hline Hawes Water & 60 & 1951 & - & LG & CG8/9 & - & $A$ \\
\hline Jack Scout & 60 & 1967 & - & LG & $\mathrm{CG} 1 / 2 / 9$ & - & $\mathrm{C}$ \\
\hline Jack Scout, opposite & 60 & 1988 & - & LG & CG8 & - & B \\
\hline Red Rake & 60 & 1979 & 2000 & LG & - & - & $X$ \\
\hline The Row & 60 & 1980 & 2000 & LG & - & - & $X$ \\
\hline The Trough, below & 60 & 1980 & $1990 \mathrm{~s}$ & LG & - & - & $X$ \\
\hline Yealand Hall Allotment & 60 & 1980 & 2000 & LG & - & - & $X$ \\
\hline Brodsworth & 63 & 1977 & $1990 \mathrm{~s}$ & LG & - & $A$ & $X$ \\
\hline
\end{tabular}


Appendix. Continued

\begin{tabular}{|c|c|c|c|c|c|c|c|}
\hline \multirow{2}{*}{ Locality } & \multirow{2}{*}{ VC } & \multirow{2}{*}{ First } & \multirow{2}{*}{ Last } & \multirow{2}{*}{ Habitat } & \multirow{2}{*}{ NVC } & \multicolumn{2}{|c|}{ Population size } \\
\hline & & & & & & $1970 \mathrm{~s}$ & $2008-15$ \\
\hline Lindrick Common & 63 & 1945 & - & LGQ & CG3/5 & $A$ & $\mathrm{~B}$ \\
\hline Wentbridge & 63 & 1953 & - & LG & CG4 & B & $\mathrm{C}$ \\
\hline Burton Leonard & 64 & 1943 & - & LG & CG2 & B & $\mathrm{C}$ \\
\hline Hetchell Crags & 64 & 1958 & c. 1976 & LG & - & $x$ & $X$ \\
\hline Jackdaw Crag Quarry & 64 & 1946 & C. 1965 & LG & - & $X$ & $X$ \\
\hline Ledsham & 64 & 2013 & - & LG & CG5 & NV & B \\
\hline Linton Common & 64 & 1946 & c. 1965 & LG & - & $X$ & $X$ \\
\hline Black Ark, south & 65 & 1950 & - & LGS & CG9 & - & $B$ \\
\hline Black Ark, north & 65 & 1950 & - & LGS & CG9 & - & B \\
\hline Greenway & 65 & 1950 & - & LGS & CG9 & - & $\mathrm{C}$ \\
\hline Thistle Green & 65 & 1950 & - & LGS & CG9 & - & B \\
\hline White Well Green & 65 & 1950 & - & LGS & CG9 & - & $\mathrm{C}$ \\
\hline Slapestone Syke & 66 & $1960 s$ & $1970 s$ & LGS & CG9 & B & $X$ \\
\hline Widdybank Fell & 66 & 1949 & - & LGS & CG9 & $\mathrm{C}$ & $\mathrm{C}$ \\
\hline Burnbarrow Scar & 69 & 1974 & - & LG & CG10 & NV & B \\
\hline Crosby Gill & 69 & 1978 & $?$ & LG & $?$ & $\mathrm{C}$ & $P$ \\
\hline Cunswick Scar & 69 & 1998 & - & LG & CG9 & NV & $\mathrm{C}$ \\
\hline Long Scar Pike & 69 & 1974 & - & LG & CG9 & $B$ & $\mathrm{D}$ \\
\hline Orton Scar & 69 & 1967 & - & LG & CG9 & $A$ & $B$ \\
\hline Pott Rigg & 69 & 2013 & - & LG & $?$ & NV & $A$ \\
\hline Ravensworth Fell & 69 & 1999 & - & LG & CG9 & NV & $\mathrm{D}$ \\
\hline Scout Scar & 69 & 1944 & - & LG & CG9 & $\mathrm{C}$ & $\mathrm{D}$ \\
\hline Arnside Knott & 69 & $1960 \mathrm{~s}$ & - & LG & CG8/9 & $\mathrm{B}, \mathrm{C}$ & $\mathrm{C}$ \\
\hline Far Arnside & 69 & 1977 & $1990 s$ & LG & - & - & $X$ \\
\hline Far Arnside, coast & 69 & 1990s & - & LG & $\mathrm{CG} 4 / 8$ & - & $B$ \\
\hline Hazelslack Tower & 69 & $1960 \mathrm{~s}$ & - & LG & CG2 & $B$ & $B$ \\
\hline Hazelslack, E of road & 69 & 1990s & - & LG & $?$ & - & B \\
\hline Hazelslack, W of road & 69 & $1990 \mathrm{~s}$ & - & LG & $?$ & - & $B$ \\
\hline Heathwaite & 69 & 2013 & - & LG & $?$ & - & $A$ \\
\hline
\end{tabular}

Notes. Habitat: CG - chalk grassland; CGE - chalk earthwork; CGH - chalk grass-heath; LG limestone grassland; LGQ - limestone grassland in disused quarry; LGS - sugar limestone grassland. NVC: CG1 - Festuca ovina-Carlina vulgaris grassland; CG2 - Festuca ovina-Avenula pratensis grassland; CG3 - Bromus erectus grassland; CG4 - Brachypodium pinnatum grassland; CG5 - Bromus erectus-Brachypodium pinnatum grassland; CG7 - Festuca ovina-Hieracium pilosella-Thymus praecox/pulegioides grassland; CG8 - Sesleria albicans-Scabiosa columbaria grassland; CG9 - Sesleria albicans-Galium sterneri grassland; CG10 - Festuca ovina-Agrostis capillaris-Thymus praecox grassland; U1 - Festuca ovina-Agrostis capillaris-Rumex acetosella grassland. Population size codes: A - 1-20; B - 21-100; C - 101-1000; D - >1000; X - not present; $\mathrm{P}$ - present but no estimate of size made; NV - not visited. 